\title{
JMSR
}

Journal of Medical and Scientific Research

\section{Antimicrobial activity of leaves extracts against bacteria isolated from wound infections}

\author{
Babbiker Mohammed Taher Goris ${ }^{1,{ }^{*}}$, Khansa Gasim Sabahalkheir ${ }^{2, *}$, Aisha Abd-albagi Ibrahim ${ }^{2}$, Aisha Abd-albagi Ibrahim ${ }^{2}$, \\ Mayada Mohammed Ishaq ${ }^{2}$ and Loui Osman Ibrahim ${ }^{2}$ \\ ${ }^{1}$ Department of Medical Microbiology, Faculty of Medical Laboratory Sciences, Sudan University of Science and technology, Sudan \\ ${ }^{2}$ Department of Microbiology, Faculty of Medical Laboratory science, Khartoum University, Sudan
}

\begin{abstract}
Background: Lawsonia inermis (L. inermis) is perennial plant commonly called henna. It is frequently cultivated in Sudan. Beside its uses cosmetics for staining hands and as hairs dyes, it was reported to be useful in jaundice, enlargement of spleen, calculus affliction and skin disease.
\end{abstract}

Method: This descriptive study was done during the period from December 2014 to April 2015 in order to determine the invitro antimicrobial activity of L. inermis (henna) leaves extract against standard and clinical isolates from wound swabs. The invitro antimicrobial susceptibly testing was performed using cup plate diffusion method. The activity of L. inermis Linn leaves extract was controlled with four reference antibiotics including gentamicin, oxacillin, ciprofloxacin, and impinim.

Results: When aqueous extract of L. inermis Linn examined against standard bacteria and clinical isolates result showed that all standard bacteria were inhibited at $100 \%, 50 \%$, and $25 \%$ concentration. All clinical isolates were successfully inhibited at $100 \%, 50 \%, 25 \%$, and $12.5 \%$. In contrary, the activity of methanolic extract of L. inermis Linn against standard bacteria showed that all standard bacteria were inhibited at $100 \%, 50 \%$ concentration, However, the clinical isolates showed an inhibition rate various depending on the concentration of methanolic extract of L. inermis Linn with $S$. aureus being most sensitive isolate.

Conclusion: We conclude that aqueous and methanolic extract of henna exhibited antimicrobial activity against all types of tested organisms both clinical and standard isolates. But the aqueous extract shows superior inhibition ability than the methanolic.

Keywords: Lawsonia inermis; antimicrobial sensitivity test; aqueous extract; methanolic extract; inhibition zone; wound infections; standard strain; clinical isolates

*Corresponding authors: Babbiker Mohammed Taher Gorish, Ph.D. in Medical Microbiology, Department of Microbiology and Immunology - Faculty of Medical Laboratory Science, Omdurman Islamic University, Sudan. Email: qorish456@gmail.com. Khansa Gasim Sabahalkheir, Department of Microbiology, Faculty of Medical Laboratory science, Khartoum University, Sudan.

Received 28 March 2019; Revised 30 May 2020; Accepted 13 June 2020; Published 22 June 2020

Citation: Goris BMT, Sabahalkheir KG, Ibrahim AA, Ibrahim AA, Ishaq MM, Ibrahim LO. Antimicrobial activity of leaves extracts against bacteria isolated from wound infections. J Med Sci Res. 2020; 8(3):114-120. DOI: http://dx.doi.org/10.17727/ JMSR.2020/8-16

Copyright: (C) 2020 Goris BMT et al. Published by KIMS Foundation and Research Center. This is an open-access article distributed under the terms of the Creative Commons Attribution License, which permits unrestricted use, distribution, and reproduction in any medium, provided the original author and source are credited. 


\section{Introduction}

Lawsonia inermis (L. inermis) is a glabrous branched small tree, 2-6 $\mathrm{m}$ in height. Leaves are small, opposite, entire margin elliptical to broadly lance late, subsessile, 1.5 to $5 \mathrm{~cm}$ long, $0.5-2 \mathrm{~cm}$ wide, greenish brown to dull green, petiole short and obtuse apex with tapering base [1-5]. L. inermis is perennial plant commonly called henna. Often cultivated in North Africa, south East Asia, India, Persia, and along the African coast of Mediterranean Sea. Henna roots may also helpful in management of the burning sensation, leprosy, skin disease, a menorrhea, a bortifacient, bitter, and premature graying of hair [6].

Wound is breach in the skin and exposure of subcutaneous tissue following loss of integrity which provides a moist, warm, and nutritive environment that is conductive for microbial colonization and proliferation [7-9]. The most common causative organisms associated with wound infections include S. aureus, MRSA, Streptococcus pyogenes, Enterococci, Pseudomonas aeruginosa, Enterobacteriaceae including Escherichia coli, Proteus species, and Klebsiella species [7].

Unfortunately, now adapts multiple drugs resistance developed due to the indiscriminate use of commercial antimicrobial drugs commonly use in the treatment of the infections disease. This situation forced scientists to search for new antimicrobial substance [10]. Therefore, it's necessary to take measure to reduce microbial resistance and to explore alternative antimicrobial sources, product is used in their natural form in traditional herbal medicines [11].

Although the wide use of henna as cosmetics in Sudan only few studies are focused on the plant as antimicrobial agent. Thus, this study tries to determine the possible antimicrobial activity of this plant on standard and clinical bacterial isolates obtained from wound infections.

\section{Methods}

This is a descriptive cross-sectional study aimed to determine the antimicrobial activity of $L$. inermis leaves extracts against some bacteria isolated from wound infections. The study was carried out during the period from December 2014 to 2015 April. The samples of wound swabs isolates were collected from Soba University hospital in Khartoum and Military Teaching hospital (Alselah Altebby) in Omdurman. The standard organisms were obtained from Laboratory Management Center in Khartoum.

\section{Sample size}

A total of 100 isolates were collected. Only 45 isolates were included in this study and these were 15 Pseudomonas aeruginosa, 15 Staphylococcus aureus, 7 Proteus species, 5 Klebsiella pnemoniae and only 3 were Escherichia coli, while 55 isolates were excluded from this study because it was a normal commensally flora of skin and it was not pathogenic. On the other hand, standard strains bacteria (Staphylococcus aurous ATCC: 29213, Escherichia coli ATCC: 25922, Pseudomonas aeruginosa ATCC: 27853) were obtained from the management of laboratory center. Both clinical isolates and standard bacterial strains were tested for their susceptibility to the reference antibiotics imipenem $(10 \mathrm{mcg} / \mathrm{disc})$. Ciprofloxacin (5mcg/disc), gentamicin $(10 \mathrm{mcg} /$ disc), oxacillin $(5 \mathrm{mcg} /$ disc $)$ and henna leaves methanolic and aqueous extracts.

\section{Bacteria culture and identification}

All wound swabs samples were cultivated on blood agar and MacConkey agar media and incubated aerobically at $37^{\circ} \mathrm{C}$ for overnight. Then the Isolated bacteria were purified and identified by using available gram stain and biochemical test according to the standard method of bacteria isolation and identification [8]. All process was done under strict sterile condition to avoid any unnecessary contamination.

\section{Preparation of the henna cured extracts}

\section{Preparation of the L. inermis aqueous and} methanol extract

Extraction was carried-out following a method described by Merdaw in 2009 [12]. After complete dryness the yield percentage was calculated as followed:

$$
\frac{\text { (Weight of the extract obtained) }}{\text { (Weight of plant sample) }} \times 100
$$

\section{Preparation of serial dilution of the extracts}

12 gram of extract was dissolved in $12 \mathrm{ml}$ of distill water, this was considered as $100 \%$ concentration, and then a serial of dilution was prepared by the 
formula: Required volume * Original concentration/ required volume), )50\% concentration: $2.5 \mathrm{ml}$ of extract in $2.5 \mathrm{ml}$ DW), (25\% concentration: $1.25 \mathrm{ml}$ of extract in $3.75 \mathrm{ml} \mathrm{DW}),(12.5 \%$ concentration: $0.37 \mathrm{ml}$ of extract in $2.32 \mathrm{ml} \mathrm{DW}), 6 \%$ concentration: $(0.108 \mathrm{ml}$ of the extract in $1.70 \mathrm{ml} \mathrm{DW})$.

\section{Sterilization of the prepared L. inermis (henna) leaves extracts}

Bulk of serial dilutions of L. inermis leave extracts were sterilized by autoclave at $121^{\circ} \mathrm{C}$ for 15 minutes.

\section{Preparation of standard bacterial suspension}

Each bacterial strain suspension was prepared as follow: by sterile the wire loops a small part of the single colony was emulsified in a $0.5 \mathrm{ml}$ of sterile normal saline, and then the optical density of the standard bacterial suspensions was read in colorimeter filter 660 against McFarland standard (Optical density 0.09_ 0.12) [8].

\section{The study of the antimicrobial effect of the $L$. inermis (henna) leaves extracts}

The cup plate method was used. A simple device was used to remove the disk of agar from the medium. It consists of a thin walled steel cylindrical chamber measuring $10 \mathrm{~cm}$ in length and having a diameter of $1 \mathrm{~cm}$, the cutting edge was beveled on the inside. Placing the open end of the champer on the surface of a poured agar plate, the disc was cut easily with slight pressure. Then placing $0.1 \mathrm{ml}$ of extract in the hole using automatic pipette. Then incubated for 1820 hours at $37^{\circ} \mathrm{C}[8]$. After which zone of inhibition was measured.

\section{The study of the reference antibiotic}

The stander disc diffusion method was used. Muller Hinton agar is inculcated with the bacteria suspension by swabbing across the plate, and then the disc was placed by sterile forceps in the plate. The plate is then incubated at $37^{\circ} \mathrm{C}$ for $18-20$ hours [8]. After which zone of inhibition was measured.

\section{Data analysis}

Data were analyzed by using computer based programmed Excel and Statistical Package for Social Science (SPSS).

\section{Results}

In this study four antibiotic were used as reference antibiotic (Gentamicin, oxacillin, imipenem, and ciprofloxacin). The inhibition zone of standard bacteria (Gram positive and Gram negative) has been tested against the reference antibiotics. The gram positive (S. aureus) was sensitive to both gentamicin and oxacillin, and the gram-negative bacteria were sensitive against both imipenem and ciprofloxacin.

The studied antibacterial activity of L. inermis Linn aqueous extract against standard bacteria showed that all organisms were inhibited at $100 \%, 50 \%$, and $25 \%$ concentration, except the staphylococcus aureus was also inhibited at $12.5 \%$ concentration (Figure 1) (Table 1). Also studied antibacterial activity of L. inermis Linn methanolic extract against standard bacteria showed that all organism was inhibited at $100 \%, 50 \%$ concentration, except the S. aureus was also inhibited at $25 \%, 12.5 \%$, and $6 \%$ concentration and Pseudomonas aeruginosa was also inhibited at $25 \%$ concentration (Table 1 ).

Table 2, show the mean inhibition zone diameter in mm of L. inermis Linn aqueous extract against clinical isolates tested and the number of the isolate that were inhibited by each concentration. The $100 \%, 50 \%$, $25 \%$, and $12.5 \%$ concentrations were successfully inhibiting all the tested isolates. In contrary, Table 5 shows the mean inhibition zone diameter in $\mathrm{mm}$ of $L$. inermis Linn methalonic extract against clinical isolates tested and the number of the isolate that were inhibited by each concentration. The $100 \%$, $50 \%, 25 \%$, and $12.5 \%$, and $6 \%$ concentrations were successfully inhibiting all the $S$. aureus isolates. All E. coli isolates were inhibited by the $100 \%$ and $50 \%$, and none of the isolates where inhibited by the $25 \%$, $12.5 \%$, and $6 \%$ concentrations. Proteus species isolates were all inhibited by the $100 \%, 50 \%$, and $25 \%$ concentrations. And four were inhibited by $12.5 \%$ concentrations, while $6 \%$ concentration fails to inhibit any isolates. Klebsiella pneumoniae isolates were inhibited by all concentrations except $12.5 \%$ concentration inhibited one isolates and the 6\% concentration fail to inhibitany isolates. Pseudomonas aeruginosa isolates were entirely inhibited by $100 \%$, $50 \%$, and $25 \%$ concentrations, and ten isolates were inhibited by $12.5 \%$ concentrations, and none were inhibited by $6 \%$ concentrations (Table 2 ).

Our result also demonstrates that a $100 \%$, and $50 \%$ concentrations of the aqueous and methanolic 
extracts show a more activity against gram positive bacteria comparing to the reference antibiotic which used in this study. However, the 25\% and $12.5 \%$ concentration of both extracts show less inhibition activity.

Result of this study show that a $100 \%$, and $50 \%$ concentrations of the aqueous and methanolic extracts have a more efficacy against gram negative isolates than a reference antibiotic Ciprofloxacin, while the impinem show more activity than the aqueous and methanolic extract. And the other concentration shows less or no antibacterial activity.

Additionally, our result determined a clear superior antibacterial activity with both the aqueous and methanolic extracts concentration against the methicillin resistance staphylococcus aureus (MRSA) isolates, comparing with the reference antibiotic oxacillin.

Table 1: The inhibition zone diameter in ( $\mathrm{mm}$ ) of L. inermis Linn leaves (henna) methanolic extract and aqueous extract against the standard organisms (controls).

\begin{tabular}{|lccccc|}
\hline \multicolumn{7}{|l}{ Oqueous extract concentrations $\%(\mathrm{v} / \mathrm{v})$} & & & \\
\hline & $100 \%$ & $50 \%$ & $25 \%$ & $12.5 \%$ & $6 \%$ \\
\hline Staphylococcus aurous & $25 \mathrm{~mm}$ & $23 \mathrm{~mm}$ & $20 \mathrm{~mm}$ & $17 \mathrm{~mm}$ & - \\
Escherichia coli & $19 \mathrm{~mm}$ & $16 \mathrm{~mm}$ & $14 \mathrm{~mm}$ & - & - \\
Pseudomonas aeruginosa & $21 \mathrm{~mm}$ & $19 \mathrm{~mm}$ & $16 \mathrm{~mm}$ & - & - \\
\hline Methanolic extract concentrations $\%(\mathrm{v} / \mathrm{v})$ & & & & $6 \%$ \\
\hline & $100 \%$ & $50 \%$ & $25 \%$ & $12.5 \%$ & $11 \mathrm{~mm}$ \\
\hline Staphylococcus aurous & $34 \mathrm{~mm}$ & $22 \mathrm{~mm}$ & $20 \mathrm{~mm}$ & $19 \mathrm{~mm}$ & - \\
Escherichia coli & $16 \mathrm{~mm}$ & $15 \mathrm{~mm}$ & - & - & - \\
Pseudomonas aeruginosa & $19 \mathrm{~mm}$ & $15 \mathrm{~mm}$ & $12 \mathrm{~mm}$ & - & - \\
\hline
\end{tabular}

Note: - = no zone of inhibition, $\mathrm{mm}$ = millimeter.

\section{Discussion}

The search for substitute medicine rather than chemical antimicrobial drug is an important line of search because of the resistance acquired by many bacteria [3].

In our study, the L. inermis Linn leaves aqueous and methanolic extracts have shown very good antibacterial activity against all clinical bacterial isolates. The aqueous extract of henna showed highest activity than methanolic extract and give wide diameter of inhibition zone against the clinical isolates and the standard bacteria of Staphylococcus aurous species, Escherichia coli, Proteus species, Klebsiella pneumonia, and Pseudomonas aeruginosa. These results are in agreement with many other studies mentioned next. In 2005, Muhammad and Muhammad found through in vitro studies that the water extract was superior in inhibition of microorganism that is involved in burn wound infections [13]. Also in 2007 a study carried by Abdulmoneim Saadabi was reported that the extract of water was clearly superior in inhibition activity of Staphylococcus aureus, Escherichia coli and Pseudomonas aeruginosa, followed by methanol then the chloroform [14]. In 2009 Medraw report that water and chloroform crude extracts of the henna leaves in different concentration were studied and the extract of water was clearly superior for all bacteria tested especially the bacteria Staphylococcus aureus from Gram positive [12].

However, our study in L. inermis Linn leaves was in disagreement with studies below, a study conducted by Al-Rubiay et al., in 2008 reported that in compare with oily extract the alcoholic extract had the highest antibacterial activity on Staphylococcus aureus, Staphylococcus epidermidis, Pseudomonas aeruginosa species and beta hemolytic streptococci [15]. 
Table 2: The mean of the inhibition zone diameter in ( $\mathrm{mm}$ ) of L. inermis Linn leaves (henna) methanolic extract and aqueous extract against the bacterial isolates.

\begin{tabular}{|c|c|c|c|c|c|c|c|c|c|c|c|}
\hline Organisms & Total & $\begin{array}{c}\text { Aqueous extract } \\
\text { concentrations }(\mathrm{v} / \mathrm{v}) \%\end{array}$ & & & & & & & & & \\
\hline & & $100 \%$ & & & & & & & & $6 \%$ & \\
\hline & & $N$ & $\begin{array}{c}M \\
(\mathrm{~mm})\end{array}$ & $N$ & $\begin{array}{c}M \\
(\mathrm{~mm})\end{array}$ & $N$ & $\begin{array}{c}M \\
(\mathrm{~mm})\end{array}$ & $N$ & $\begin{array}{c}M \\
(\mathrm{~mm})\end{array}$ & $N$ & $\begin{array}{c}M \\
(\mathrm{~mm})\end{array}$ \\
\hline $\begin{array}{l}\text { Staphylococcus } \\
\text { aurous }\end{array}$ & 15 & 15 & 33 & 15 & 21 & 15 & 20 & 15 & 16 & 15 & 0 \\
\hline Escherichia coli & 3 & 3 & 23 & 3 & 17 & 3 & 9 & 3 & 7 & 2 & 0 \\
\hline Proteus spp. & 7 & 7 & 19 & 7 & 18 & 7 & 15 & 6 & 12 & 6 & 0 \\
\hline $\begin{array}{l}\text { Klebsiella } \\
\text { pneumonia }\end{array}$ & 5 & 5 & 17 & 5 & 15 & 5 & 14.4 & 5 & 8 & 3 & 0 \\
\hline \multirow[t]{4}{*}{$\begin{array}{l}\text { Pseudomonas } \\
\text { aeruginosa }\end{array}$} & 15 & 15 & 16 & 15 & 14 & 15 & 10 & 14 & 0.7 & 11 & 0 \\
\hline & Total & \multicolumn{10}{|c|}{ Methanolic extract concentrations ( $\mathrm{v} / \mathrm{v}) \%$} \\
\hline & & \multicolumn{2}{|l|}{$100 \%$} & \multicolumn{2}{|c|}{$50 \%$} & \multicolumn{2}{|c|}{$25 \%$} & \multicolumn{2}{|c|}{$12.5 \%$} & \multicolumn{2}{|c|}{$6 \%$} \\
\hline & & $N$ & $\begin{array}{c}M \\
(\mathrm{~mm})\end{array}$ & $N$ & $\begin{array}{c}M \\
(m m)\end{array}$ & $N$ & $\begin{array}{c}M \\
(m m)\end{array}$ & $N$ & $\begin{array}{c}M \\
(m m)\end{array}$ & $N$ & $\begin{array}{c}M \\
(\mathrm{~mm})\end{array}$ \\
\hline $\begin{array}{l}\text { Staphylococcus } \\
\text { aurous }\end{array}$ & 15 & 15 & 26 & 15 & 21 & 15 & 19 & 9 & 15 & 1 & 3 \\
\hline Escherichia coli & 3 & 3 & 19 & 3 & 16 & 3 & 0 & 0 & 0 & 0 & 0 \\
\hline Proteus spp. & 7 & 7 & 16 & 7 & 17 & 7 & 9 & 4 & 0 & 0 & 0 \\
\hline $\begin{array}{l}\text { Klebsiella } \\
\text { pneumoniae }\end{array}$ & 5 & 5 & 17 & 5 & 15 & 5 & 3 & 1 & 0 & 0 & 0 \\
\hline $\begin{array}{l}\text { Pseudomonas } \\
\text { aeruginosa }\end{array}$ & 15 & 15 & 19 & 15 & 16 & 15 & 8 & 10 & 0.7 & 1 & 0 \\
\hline
\end{tabular}

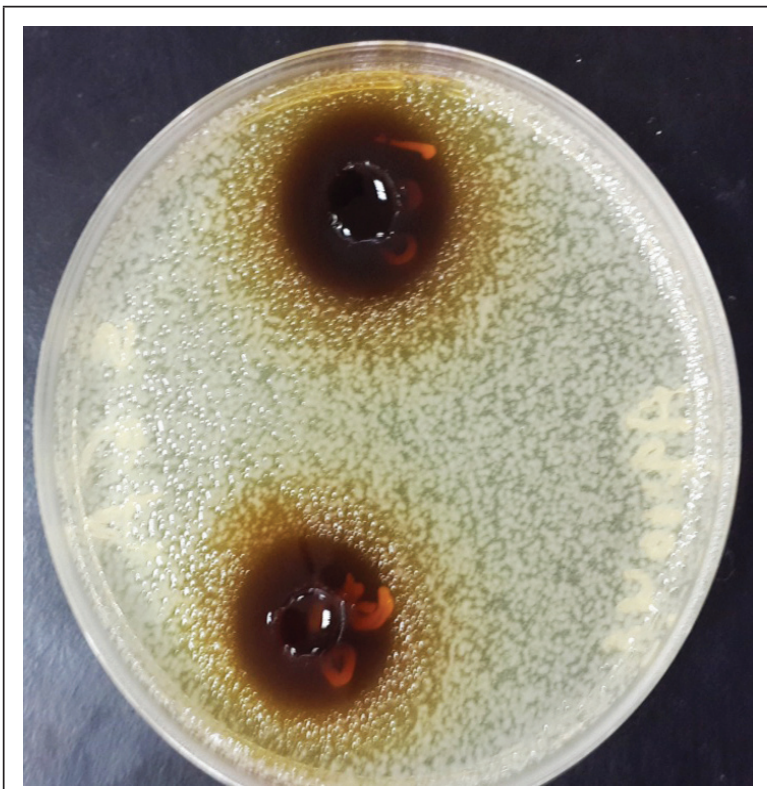

Figure 1: $100 \% \& 50 \%$ concentration of aqueous extract against Staphylococcus aureus.
In contrary, study of Hussein et al. in 2011 [16], of watery, methanolic and chloroform extract of $L$. inermis leaves, investigated by agar well diffusion on Escherichia coli, Pseudomonas species and Proteus species. The antibacterial activity of chloroform extract was the most effective, followed, followed by methanol extract, while water extract had no effect or had just a little effect and this study been dramatically in disagreement with our finding.

In our study, L. inermis Linn extracts exhibited activity against the selected bacterial isolates and control strains. Watery extract of L. inermis produced significant diameter of inhibition zone for both gram negative and gram-positive bacteria.

Comparing of inhibition zone of aqueous and methanolic extract against (clinical and standard) bacterial isolates and the reference antibiotics result in that gram-positive isolates produce larger 
inhibition zone than gentamicin at concentration of $100 \%$ (methanolic, aqueous), same inhibition zone at $50 \%$ and less inhibition zone at $12.5 \%$. But oxacillin show higher inhibition zone than concentrations of $50 \%, 25 \%, 12.5 \%$. And small inhibition zones at $100 \%$ concentrations.

However, Gram negative Escherichia coli show higher inhibition zone than ciprofloxacin at concentration $100 \%, 50 \%$ in aqueous extract and methanolic extract show higher activity at $100 \%$ concentration but similar activity at 50\%. Imipenem had higher activity than both extracts. The imipenem and ciprofloxacin had higher activity on Proteus species, Klebsiella pneumonia and Pseudomonas aeruginosa than both extracts at all concentrations. Also pigmented strains of pseudomonas were more resistant to both extracts of henna leaves.

Three MRSA were identified based on oxacillin sensitivity. The mean diameter of inhibition zone of methanolic extract at concentrations 100\%, 50\%, $25 \%, 12.5 \%$, and $6 \%$ were more effective than the oxacillin. And also, the mean inhibition zone diameter in aqueous extract at concentrations of $100 \%, 50 \%$, $25 \%$, and $12.5 \%$, were higher than the oxacillin.

\section{Conclusion}

In conclusion, Sudanese henna leaves extract revealed antibacterial activity against the bacteria responsible for the common wound infection in Sudan. Aqueous and methanolic henna extracts have similar effects to some of the antibiotics commonly used in treating this infection. Our results confirm earlier studies on L. inermis Linn (henna) leaves extracts.

\section{Limitation}

We use only 4 antibiotics as control. Instead, further studies should include more antibiotics as reference controls. Due to the lacking of funding we did not determine the Minimum Inhibitory Concentration (MIC) of L. inermis Linn leaves both the aqueous and methanolic extracts, so further study should consider this point.

\section{Ethics approval and consent to participate}

Approval was taken from Research Ethic Committee of Khartoum University (under permission number UKH1203 September 2014) and verbal consent was taken from each patient. And all the information's taken were treated confidentially and it was used for research purpose.

\section{Availability of data and material}

Data and material are available under request.

\section{Authors' contributions}

BG, KG, MM and AA collect and analyze the samples. $\mathrm{KG}, \mathrm{AA}$ and MM write the final Manuscript. BG and LO make proof reading.

\section{Acknowledgments}

The author is very grateful to patients for their corporation. The author's apperception extended to the hospitals staff for their assistance.

\section{Conflicts of interests}

Authors declare no conflicts of interest.

\section{References}

[1] Zhang Qi. Traditional and Complementary Medicine. World Health Organisation headquarters in Geneva, 2010.

[2] Petrovska BB. Historical review of medicinal plants' usage. Pharmacogn Rev. 2012; 6(11):1-5.

[3] Benzie IFF, Wachtel-Galor S. Herbal Medicine: Biomolecular and clinical aspects. 2nd ed. Boca Raton (FL): CRC Press/ Taylor \& Francis; 2011.

[4] Wachtel-Galor S, Benzie IFF.Herbal Medicine:An introduction to its history, usage, regulation, current trends, and research needs. In: Benzie IFF, Wachtel-Galor S, eds. Herbal Medicine: Biomolecular and Clinical Aspects. 2nd ed. Boca Raton (FL): CRC Press/Taylor \& Francis; 2011.

[5] Singh M, Kaur M, Dangi CBS, Singh H. Phytochemical \& TLC Profile of Lawsonia Inermis (Heena). Int J Pharm Res Schol. (2014); 3(1):624-634.

[6] Makhija IK, Dhananjaya DR, Kumar SV, Devkar R, Khamar $D$, et al. Lawsonia inermis from traditional use to scientific assessment. Afr J Pharmaceut Sci Pharm. 2011; 2(1):145e65.

[7] Bowler PG, Duerden BI, Armstrong DG. Wound microbiology and associated approaches to wound management. Clin Microb Rev. 2001; 14(2):244-269.

[8] Cheesbrough, M. Frontmatter. In district laboratory practice in tropical countries; Cambridge University Press: Cambridge, 2005; pp: 253-258.

[9] Daihan S, Al-Faham M, Al-shawi N, Almayman RB, Zargar S, et al. Antibacterial activity and phytochemical screening of some medicinal plants commonly used in Saudi Arabia against selected pathogenic microorganisms. Journal of King Saudi University of Sciences 2013; 25(1):115-120.

[10] Rahmoun N, Boucherit-Otmani Z, Boucherit K, Benabdallah M, Choukchou-Braham N. Antifungal activity of the Algerian Lawsonia inermis (henna), Pharmac Biol. (2013); 51(1):131-135. 
[11] Ali NA, Jülich WD, Kusnick C, Lindequist U. Screening of Yemeni medicinal plants for antibacterial and cytotoxic activities. J Ethnopharmacol. 2001; 74(2):173-179

[12] Merdaw MA. Inhibition of bacterial growth by Lawsonia inermis (henna) leaf extracts in vitro. Ibn Al-Haitham J Pure Appl Sci. 2009; 22(4):32-38

[13] Muhammad HS, Muhammad S. The use of Lawsonia inermis linn (henna) in the management of burn wound infections. Afr J Biotechnol. 2005; 4(9):934-937.

[14] Saadabi MAA, Evaluation of Lawsonia inermis linn (Sudanese henna) leaf extract as an antimicrobial agent. Res J Biol Sci. 2007, 2(4):419-423.

[15] Al-Rubiay KK, Jaber NN, Al-Mhaawe BH, Alrubaiy LK. Antimicrobial efficacy of henna extracts. Oman Med J. 2008; 23(4):253-256.

[16] Hussein N. Antibacterial activity of henna plant Lawsonia inermis on gram negative bacteria. Al- Mustansiriyah J. Sci. 2011; 22(7):22. 